\title{
SELF-CENSORSHIP LICENSED RELIGIOUS OF NEWS MEDIA FOR BALANCED JOURNALISM TO SUPPORT HARMONY AND HUMAN PROGRESS
}

\author{
Amar Ma'ruf \\ Email : amarsanis92@gmail.com \\ University of Asahan, North Sumatera
}

\begin{abstract}
Religion is a belief in the existence of a supernatural power who created and controls the universe. These days, Islam is often associated with terrorism so as to create Islamophobia. Distortion of information by the media decrease the good image of Islam. These days, many acts of terrorism going on in the world, but if not too highlighted if terrorists are not Muslims. Many civilians have been killed in Palestine, Syria, Afghanistan, and other countries have been killed, but it is not too claimed to be an act of terrorism as well as acts of terrorism that occurred in western countries which incidentally is known culprit is Muslim. One of the ways that have a major impact is the need to be made regarding the rules of self-censorship licensed religious for the news media. Technical implementation of the self-censorship licensed religious use of risk management. The principle is prevention. Prevention of the media to present imbalance in the news much better benefits than giving punishment to the media which wrong in presenting the news. If self-censorship is implemented, not only the equal of news that will be obtained, but the moral improvement of mankind will be achieved, given the media is a tool that easily influence the human mind. Thus proved that the acts of terrorism that confront terrorist act of taking his religion is just a scapegoat in the group seemed to be the face of the religion.
\end{abstract}

Key words: self-cencorship, religious, news, journalism, harmony

\section{INTRODUCTION}

Authors begin this article with a quote said by one of the world's Nobel laureates figures from Germany, Albert Einstein. Einstein said that science without religion is blind. Without religion, science to be without direction.
As a general definition that is widely used, Oxford Student Dictionary defines that religion is a belief in the existence of a supernatural power who created and controls the universe. Based on these definitions, then all science products must follow the rules of God 
the creator and controller of the universe for human beings in the world are not misdirected and not damaged.

News and its devices are all a product of science. News including human needs. News is displayed through print and digital media. There are many definitions of the news. Among them by Lyle M. Spencer in News Writting books and according to William S. Maulsby in the book Getting in News. Both of these definitions are widely used to study literature. Sepencer defines the news is true or correct ideas and can attract the majority of readers. While William S. Maulsby define news is a narrative correctly and impartially on the facts that have significance and the recent attention-grabbing news reader. From this definition as well as from two other definition, there are three important principles of the news that is up to date, contains the truth, and equal or impartial.

However, unfortunately these days there are bullies harmony of human through the news. Distortion of information is easy to form an image for the world community. Disharmony triggered by news that tends to discriminate against any religion or ethnicity so as to discriminate against adherents as well. These days, Islam is often associated with terrorism so as to create Islamophobia. As one proof is the growing number of studies that reconcile Islam with terrorism. Distortion of information by the media decrease the good image of Islam. Yusuf Estes, a former pastor from the United States who converted to Islam since 1991 say that distorted information about Islam is still found in the newspapers and television world. Now, the distortion of information more widely with the development of digital information media. Edward Said said that the media and Western scholars see Islam and Muslims for most European and American society is news, especially the unpleasant news. The impact that occurs is due to the rampant Islamophobia news is not balanced. The term Islamophobia became known in the 1980s. The term Islamophobia is increasingly being used after the tragedy of September 11, 2001. In 1997, Runnymede Truts, an Thing Tank institution in the UK defines Islamophobia as dread or hatred of Islam that gave rise to the same feelings 
towards Muslims. Rowan Wolf in an article entitled An Introduction to Islamophobia and Anti-Arabism mention Islamophobia is prejudice and hostility directed at Muslims in general generalized by most Western nations are Arabs. Islam as a threat. In 2012, sociologist Detlef Pollack showed half of Germans see Islam as a threat and does not fit side by side with the western world. Here the percentage of citizens of some countries that portray Islam as a threat: Germany $51 \%$, Spain $60 \%$, Switzerland 50\%, USA $42 \%$, India 30\%, South Korea 16\%. In fact, the study describes Islam as a religion of fanaticism and aggressive while Buddhism and Hinduism is a religion of peace.

\section{DISCUSSION}

\section{Terrorism and Islamophobia}

Terrorism synonymous with violence. Terrorism is the apex of violance. Victims of terrorism are often the people who are not guilty. According to Walter Laqueur, Terrorism consitutes the illegitimate use of force to Achieve a political objective when innocent people are targeted. And there are many other definitions of terrorism.

These days, many acts of terrorism going on in the world, but if not too highlighted if terrorists are not Muslims. Many civilians have been killed in Palestine, Syria, Afghanistan, and other countries have been killed, but it is not too claimed to be an act of terrorism as well as acts of terrorism that occurred in western countries which incidentally is known culprit is Muslim. In Islam people who commit terror, murder, or other crimes is a major sin. Such as murder. In the Qur'an Surah Al Maidah: 32-described "Whoever kills a human being, not because people were (kill) another person, or for causing corruption in the earth, it is as if he has killed all mankind." The majority religion The world condemned the acts of terrorism. In the Bible, Deuteronomy 5:17 also ordered to not kill. However, as there are double standards in western media which associate Islam with terrorism. Islam as close to terrorism.

So that Islamophobia does not continue to happen, it is necessary to balance the news broadcast to fit the facts and equal. It is beneficial to people 
of other faiths. To avoid phobia-phobia against religions in the world.

\section{Self Cencorship For News Media}

One of the ways that have a major impact is the need to be made regarding the rules of self-censorship licensed religious for the news media. The concept is like other standardization organizations, such as the International Standards Organization (ISO) and Hazard Analysis Critical Control Point (HACCP). Self-censorship is functioning filter any news, both in print and digital media before it is presented to the public. Self censorship licensed religious involves the clerics from each religion to work together to consider whether the presentation of news is already balanced, fit the facts, no interests. In Indonesia and other Islamic countries, the concept of religious licenses are commonly used, such as for food with halal labeling. News as human needs would need to obtain a religious license. Repeat of what was said by Einstein, that science without religion is blind. The products of science are transformed into human needs, it would be dangerous if it is not paired with religion.

Technical implementation of the self-censorship licensed religious use of risk management. The principle is prevention. Prevention is better than repair so its efforts more structured and intensive because the benefits are greater. Tim self-censorship routinely recheck the news content will be presented. However, it should be underlined that the institution's selfcensorship only served to filter, do not set the editorial team in determining the blueprint news. It aims for the independence of the news media as an independent institution.

Prevention of the media to present imbalance in the news much better benefits than giving punishment to the media which wrong in presenting the news. Thus it needs to make the rules, or even the rules set out in the summit of the world regarding the obligation of news media organizations that have self-censorship licensed religious institutions in which consists of the religious clerics and scholars in the field of news censorship. The religious clerics elected licensed by the ministry of religious legality of each 
country. If self-censorship is implemented, not only the equal of news that will be obtained, but the moral improvement of mankind will be achieved, given the media is a tool that easily influence the human mind. People do want to always be free, but that freedom must be restricted by religious rules in order to avoid damage.

Thus proved that the acts of terrorism that confront terrorist act of taking his religion is just a scapegoat in the group seemed to be the face of the religion. Though not. Thus, the logic is wrong if linking religious sanctity to the crime. Religions teach goodness. Correct logic is to connect people who are not religious to the crime caused. The correlation is more and more people who do not adhere to his religion, the more crime caused.

To end this article, author would like to say that stated in the Qur'an Surah Al-Isra ': 81 "and Say:" Truth has come and falsehood has vanished. "Verily falsehood is something that is definitely gone." Everything will be beautiful in time. In the old Testament book of Ecclesiastes 3: 1 "for everything there is a season, for every matter under heaven."

\section{CONCLUSION}

One of the ways that have a major impact is the need to be made regarding the rules of self-censorship licensed religious for the news media. Technical implementation of the selfcensorship licensed religious use of risk management. The principle is prevention. Prevention of the media to present imbalance in the news much better benefits than giving punishment to the media which wrong in presenting the news. If self-censorship is implemented, not only the equal of news that will be obtained, but the moral improvement of mankind will be achieved, given the media is a tool that easily influence the human mind.

\section{REFERENCES}

Al Qur'an Al Karim

Bible

Maulsby, William S. 1925. Getting the news. New York. Harcourt. Brace and Company

Ma'ruf, A. 2014. Move On. Forthisa Karya

Spencer, M. Lyle. 1917. News writing. Boston. 
Volume 3 Nomor 2, Oktober 2017

Runnymede Trust. 1997. The Islamophobia: a challenge for us all. Allen, C. \& Nielsen, J

Pollack, Detlef. 2012. Memantau Agama. Bertelsmann Foundation, Jerman.

Said, Edward W. 1981. Covering Islam: How the Media and the Experts Determine How We See the Rest of the World. New York: Pantheon Books.

Jasafat. 2014. Distorsi Terhadap Islam: Analisis Pemberitaan Media Barat. Jurnal Ilmiah Peuradeun.

Wolf, Rowan. An Introduction to Islamophobia and anti-arabism. Portland Community Collage

Yusuf Estes Talk About Islam in auditorium Griffith University (GU), Brisbane, Australia, Thursday, 30 ${ }^{\text {th }}$ September 2008 